\title{
ŞEYH MAHMUD BİN EDHEM VE TUHFETÜ'L-EDEB'i
}

\section{Abdülbaki ÇETIIN*}

\section{Özet}

Şeyh Mahmud bin Edhem, II. Bayezit devri (saltanatı: 1481-1512) âlimlerindendir. Dil bilgisi, sözlük, inşa, akaid ve fikıh dallarında eser vermiştir.

Şeyh Mahmud bin Edhem'in dilbilgisi dalında dört; sözlük, inşâ, akaid ve fikıh dallarında ise birer eseri olmak üzere sekiz eseri bulunmaktadır.

Tuhfetü'l-Edeb, Şeyh Mahmud bin Edhem'in Arapçanın morfolojisini konu alan Türkçe eseridir. Eserde kelime türetme (iştikak) fiil çekimi (tasrif) ve asli (kök) harflerine göre kelime türleri üzerinde durulmuştur. Şeyh Mahmud bin Edhem, Minhâcü'l-Edeb adlı Arapça eserinde de aynı konuları ele almıştır.

Anahtar Sözcükler: Şeyh Mahmud bin Edhem, Tuhfetü’l-Edeb, Osmanlı Türkçesi, dil bilgisi, Türkçe yazmalar.

\section{SHEIKH MAHMUD BIN ADHAM AND HIS TUHFAT AL-ADAB}

\section{Abstract}

Sheikh Mahmud bin Adham is one of the scholars of Bayezit II speed (reign: 1481-1512). His works include grammar, lexicography, chancery, aqaid and fiqh branches.

He has eight works. Four of them are on grammar, and one of them on lexicography, chancery, aqaid and fiqh branches.

Tuhfat al-Adab is Sheikh Mahmud bin Adham's Turkish work on morphology of Arabic grammar. In this work, he focused on derivation of the words, conjugations and the types of words based on the essential (root) letters. Sheikh Mahmud bin Adham also dealt with the same subjects in his Arabic work Minhac al-Adab.

Keywords: Sheikh Mahmud bin Adham, Tuhfat al-Adab, Ottoman Turkish, grammar, Turkish manuscripts.

XV. yüzyılın ikinci yarısı ile XVI. yüzyılın başlarında yaşamış Şeyh Mahmud bin Edhem, Akşehirli bir babanın oğlu olarak Amasya'da doğmuştur. Nakşibendi şeyhlerindendir. ${ }^{1}$

Hayatı hakkında fazla bilgi sahibi olmadığımız Şeyh Mahmud bin Edhem, II. Bayezit devri (saltanatı: 1481-1512) âlimlerindendir. ${ }^{2}$

Şeyh Mahmud bin Edhem, Rumeli kazaskeri iken 1486 yllında görevinden azledilen ${ }^{3}$ Mevlâ Kastallanî diye de bilinen Kestelli Muslihuddin Mustafa’nın (öl. 1496) damadıdır. ${ }^{4}$

\footnotetext{
${ }^{*}$ Doç. Dr.; Bingöl Üniversitesi Fen Edebiyat Fakültesi Türk Dili ve Edebiyatı Bölümü, abdcetin@gmail.com.

${ }^{1}$ Bursalı Mehmed Tahir, Osmanlı Müellifleri I, 160.

2 Şeyh Mahmud bin Edhem, II. Bayezit'e dört eser sunmuştur. Miftâhu'l-Luga, Gülşsen-i İnşâ, Hâş̧iyetü Mahmûd bin Edhem 'alâ Şerhi'l-Akâ'id, Müntehabü'l-Fetâva'l-Hâniyye (Muhtasar-ı Fetâvâ-yı Kadıhan).
} 
Şeyh Mahmud bin Edhem dilbilgisi, sözlük, inşa, akaid ve fıkıh dallarında eser vermiş bir âlimdir. ${ }^{5}$ Arapça ve Farsçaya bu dillerin gramerini yazacak ölçüde hâkimdir. ${ }^{6}$

Şeyh Mahmud bin Edhem'in ne zaman ve nerede öldüğünü bilmiyoruz. ${ }^{7}$

\section{Eserleri}

Şeyh Mahmud bin Edhem'in dil bilgisi dalında dört; sözlük, inşâ, akaid ve fikıh dallarında ise birer eser olmak üzere sekiz eseri vardır.

Eserlerinden bazılarını oğlu Abdüllatif'in eğitimi için kaleme almıştır. Dört eserini Sultan II. Bayezit (saltanatı: 1481-1512)'e sunmuştur.

\section{Dil bilgisi}

Şeyh Mahmud bin Edhem'in dil bilgisi ile ilgili dört eseri vardır. İkisi Arapçanın sarfi, ikisi nahvi ile ilgili bu dört eserin üçü Arapça, biri ise Türkçedir.

\section{Minhâcü'l-Edeb}

Şeyh Mahmud bin Edhem'in oğlu Abdüllatif ${ }^{8}$ için yazdığı Arapçanın sarfı (=morfoloji) ile ilgili Arapça eseridir.

\footnotetext{
${ }^{3}$ Salih Sabri Yavuz, "Kestelî” DIA XXV, 314.

4 "Ve ene'l-fakîrü'l-hakîr ... Seyh Mahmûd bin Edhem el-ma'rûf bi-hatni’l-mevle’l-a'zam ... huccetü’l-islâm ve’lmüslimîn muslihu'l-milleti ve’d-dîn eş-şehîr bi’l-Kastallânî...” Gülşen-i İnşâ, Süleymaniye Ktp., Kadızade Mehmed 421 (müellif nüshas1), vr. 129b/7-9. Ayrıca bk. Gülşsen-i İnşâ, Staatsbibliothek, Berlin, Ms. or. oct. 2349/1, vr. 95a, (Götz II (VOHD XIII, 4), 271, Nr. 285); Fihrüsü Mahtûtâti’t-Türkiyyeti’l-Osmâniyye III, 320, Nr. 4106.

${ }^{5}$ Şeyh Mahmud bin Edhem'in "şair” olduğu iddiası (TDEA VI, 116; TDüEA VI, 190) bugün için dayanaktan yoksundur.

6 Eserlerinden Minhâcü'l-Edeb, Tuhfetü'l-Edeb, Muhtasaru'l-Îzâh ve Şerhu'l-Kâfiye (fi'n-Nahv) Arapçanın gramerine dairdir. Farsça-Türkçe bir sözlük olan Miftâhu'l-Luga'nın mukaddimesi Farsçanın muhtasar grameridir.

${ }^{7}$ Müellifimizin ismi eserlerinde ve eski kaynaklarda "Şeyh Mahmud bin Edhem” (Kâtip Çelebi, Keş̧ el-Zunun II, 1505, 1770; Bursalı Mehmed Tahir, age., I, 160) olarak geçer. Günümüz kaynaklarında ise sehven "Şeyh Mahmud b. İbrahim" (TarS. I, LII; Uzunçarş11 II, 630; Sübhanî 219) ve "Şeyh Mahmûd bin İbrâhîm Edhem" (Devellioğlu, 644; Kaya, 1996) olarak yazılmıştır. Bunların sonuncusu (Kaya, 1996) Miftâhu’l-Luga'nın Millî Ktp. Adnan Ötüken İl Halk Ktp. Koleksiyonu 141/1 numarada mukayyet nüshası üzerine yapılmıș bir yüksek lisans tezidir. Söz konusu nüshada (06 Hk 141/1) müellifin adı "Şeyh Mahmud bin Edhem" olarak geçmesine rağmen (vr. 3a/4) tezde "Şeyh Mahmud bin İbrahim Edhem" şeklinde kullanılmış ve Şeyh Mahmud bin Edhem, 935/1528-1529 tarihinde bekâr olarak ("mücerred") vefat eden "İbrahim Efendi" (Mehmed Süreyya, Sicill-i Osmanî III, 746) ile aynı kişi kabul edilmiştir (Kaya, IX, X). Kaya, ayrıca tezinin dayandığı nüshanın bulunduğu mecmuanın ikinci eseri olan Farsçanın sarfiyla ilgili bir risaleyi de (06 Hk 141/2, vr. 117b-123a) Mifttâhu'l-Luga'nın bir “bölüm”ü zannetmiş (Kaya, s. XXX) ve metnin sonuna eski harflerle eklemiştir. Kaya 60-62). Müellifin ismi üzerindeki bu karışıklık Türk Edebiyatı İsimler Sözlüğ̈̈’ne de yansımıştır: "Şeyh Mahmûd bin İbrâhîm Edhem, Seyh Mahmûd bin Edhem" (Hasan Gültekin, "Şeyh Mahmûd bin İbrâhîm Edhem, Şeyh Mahmûd bin Edhem (d.?/?-ö.897/1491-92)" Türk Edebiyatı İsimler Sözlüğ̈̈, http://www.turkedebiyatiisimlersozlugu.com/index.php?sayfa=detay\&detay=2680 (Madde yazım tarihi: 15.05.2014; erişim tarihi 20.07.2014). Buradaki ölüm tarihi de düzeltilmeye muhtaçtır. Şöyle ki müellifimizin eserlerinden Minhâcü'l-Edeb Eylül 1493, Tuhfetü'l-Edeb 1494-95, Güllşen-i İnşâ ise Ağustos 1496 telif tarihlidir.

${ }^{8}$ Kâtip Çelebi, age., II, 1870.
} 
Şeyh Mahmud bin Edhem, eserini oğlunun sarf ilmini tahsil etmeye başlaması vesilesiyle yazmıştır. Müellif bu konuda daha önce yazılmış eserlerden -isim zikretmezyararlanarak hazırladığı bu muhtasar eserini yedi bab (=bölüm) üzerine tasnif ettiğini ve Minhâcü'l-Edeb olarak adlandırdığını belirtir. ${ }^{9}$

Bu yedi bab (=bölüm) sırasıyla şunlardır:

1. Bab: Sahîh

2. Bab: Muzaaf

3. Bab: Mehmûz

4. Bab: Misâl

5. Bab: Ecvef

6. Bab: Nâkıs

7. Bab: Lefîf

Minhâcü’l-Edeb'in müellif nüshası Beyazıt Devlet Kütüphanesindedir:

Beyazıt Devlet Ktp., Beyazıt 6700/1, vr. 1b-50a. Telif tarihi: evâil-i Zilhicce 898/Eylül 1493.

Eserin bir nüshası da Süleymaniye Ktp. Yozgat 443 numaradadır. ${ }^{10}$

\section{Tuhfetü'l-Edeb}

Şeyh Mahmud bin Edhem'in Arapçanın sarfı (=morfoloji) ile ilgili Türkçe eseridir. Üzerine ayrıca durulacaktır.

\section{Muhtasaru’l-Îzâh}

Şeyh Mahmud bin Edhem, İbnü’l-Hâcib’in (öl. 646/1249) el-Kâfiye adlı Arap grameri (nahiv) ile ilgili meşhur eserini önce şerh etmiş (Şerhu'l-Kâfiye) sonra da bu şerhini ihtisar etmiştir. Bu ikinci çalışmasına Muhtasaru'l-Îzâh adını vermiştir. ${ }^{11}$

Nüshas1: Koyunoğlu Müze ve Ktp. $842 .{ }^{12}$

\footnotetext{
${ }^{9}$ Minhâcü'l-Edeb, Beyazıt Devlet ktp., Beyazıt 6700/1, vr. 1b/6-9.

${ }^{10}$ Tavsifi için bk. Mehmet Yavuz, Kuruluștan Fatih Devri Sonuna Kadar Arapça Gramer (Sarf-Nahiv)'e Dâir Eser Yazan Osmanlı-Türk Âlimleri, İstanbul Üniversitesi Sosyal Bilimler Enstitüsü (Yayımlanmamış Yüksek Lisans Tezi) İstanbul 1991, s. 186.

${ }^{11}$ Eser adı, mukaddimede "Muhtasaru'l-Îzâh” (“ve semmeytühü bi-Muhatasari’l-Îzâh” Koyunoğlu Müze ve Ktp., 842, vr. 1b/6) olarak geçer. 1a'da ve zahriyede ise farklı kalemle "Îzâh Şerh-i Kâfiye”, ve "Hâzâ Kitâbü Nû[r]i Îzâh Şerh-i Kâfiye" şeklinde kayıtlıdır.
} 


\section{4. Şerhu'l-Kâfiye}

İbnü'l-Hâcib'in (öl. 646/1249) el-Kâfiye adlı Arap grameri (nahiv) ile ilgili meşhur eserinin şerhidir. Varlığını Şeyh Mahmud bin Edhem'in Muhtasaru'l-Îzâh adlı eserinin mukaddimesinden öğreniyoruz. ${ }^{13}$

\section{Sözlük}

\section{Miftâhu'l-Luga}

Miftâhu'l-Luga, Şeyh Mahmud bin Edhem'in oğlu Abdüllatif için 896 yılının Cemaziyelahir ayının sonlarında (Mayıs 1491) yazdığı Farsça-Türkçe bir sözlük ve gramer kitabidır.

Şeyh Mahmud bin Edhem yaklaşık bir yıl sonra (897/1491-1492) eserini yeniden ele almış sözlük kısmını yaptığı eklemelerle iki misline çıkarmış ve devrin padişahı II. Bayezit'e (saltanat1: 1481-1512) sunmuştur.

İlk düzenlemenin müellif nüshası bugün Avusturya Millî Kütüphanesinde, ${ }^{14}$ ikinci düzenlemenin müellif nüshasından istinsah edilmiş bir nüshası ise İstanbul'da Süleymaniye Kütüphanesindedir. ${ }^{15}$ Miftâhu'l-Luga'nın yurt içi ve yurt dışınaki kütüphanelerde birçok nüshası vardır. Eser yayımlanmıştır. ${ }^{16}$

\section{III. İnşâ}

\section{Gülşen-i İnşâ}

Yazışma kuralları hakkında bilgi veren bir eserdir. ${ }^{17}$ Sultan II. Bayezit'e (saltanatı: 1481-1512) sunulmuştur. Kâtip Çelebi, müellifin eserini daha sonra özetlediğini (muhtasar), bu özetten de yalın bir dille mukaddime ve iki makaleden oluşan bir seçki (müntehab) hazırladığını bildirir. $^{18}$

\footnotetext{
12 bk. Eminoğlu I, 73, Nr. 842. (“Muhtasar Şerhi'l-Kafiye” adıyla); Karabulut III, 1500, Nr. 5024/1 ("El-Muhtasar fî Şerhi'l-Kâfiye - Fi’n-Nahv" adıyla); Karabulut-Karabulut V, 3576, Nr. 9698/2 ("El-Muhtasar fî Şerhi'l-Kâfiye Fi'n-Nahv" adiyla).

${ }^{13}$ Muhtasaru'l-Îzâh, Koyunoğlu Müze ve Ktp., 842, vr. 1b/3.

14 Österreichische Nationalbibliothek A. F. 448/1 (Telifi: May1s 1491).

${ }^{15}$ Süleymaniye Ktp, Kara Çelebizade 341 (Telifi: 1491-1492; istinsahı: ?).

${ }^{16}$ Abdülbaki Çetin, Şeyh Mahmûd bin Edhem: Miftâhu'l-Luga, Sonçağ Yay., Ankara 2014.

17 İçindekiler için bk. Şinasi Tekin, Menâhicü'l-İnşâ, The Earliest Ottoman Chancery Manuel by Yahya bin Mehmed el-Katib from the 15. century, Community Art Workshop. Roxbury, Mass. 1971, s. 12.

${ }^{18}$ Kâtip Çelebi, age., II, 1505.
} 
Gülşen-i İnşâ'nın Süleymaniye Kütüphanesi Kadızade Mehmed 421 numarada kayıtlı nüshası müellifin kaleminden çıkmıştır. ${ }^{19}$ (Telifi: Zilhicce 901/Ağustos 1496).

Gülşen-i İnşấ'nın kütüphanelerde birçok nüshası vardır. ${ }^{20}$

\section{Akaid}

\section{Hâşiyetü Mahmûd bin Edhem 'alâ Șerhi'l-‘Akâ’id}

Ömer b. Muhammed b. Ahmed en-Nesefî’nin Akaid'ine Taftazanî’nin yazdığı şerhe Mahmud b. Edhem'in oğlu için yazdığı ve II. Bayezit'e ithaf ettiği haşiyedir. ${ }^{21}$

Nüshas1: Topkapı Sarayı Müzesi Ktp. III. Ahmed 1743.

\section{Fıkıh (İslam Hukuku)}

1. Müntehabü’l-Fetâva'l-Hâniyye (Muhtasar-1 Fetâvâ-yı Kadıhan)

Ünlü Hanefî fakihi Kadıhan'ın Fetava (el-Fetâva'l-Hâniyye, el-Hâniyye) isimli Arapça eserinden yapılmış Arapça bir seçkidir. II. Bayezit adına düzenlenmiştir. Müellif nüshası Süleymaniye Ktp. Yozgat 317.

Telif tarihi: Evâhir-i rebiyüllevvel 896/Şubat 1491.

“Müellifin bir ad vermediği kitap müellif hatlı nüshanın kapağında Muhtasaru Kâdîhân (Süleymaniye Ktp., Yozgat, nr. 317, istinsah y1l1 896), diğer bir nüshada Müntehabü'l-Fetâva'lHâniye (Süleymaniye Ktp., Şehid Ali Paşa nr. 1080) şeklinde kaydedilmiştir."22 Kataloglarda eser "Muhtasar-ı Fetâvâ-yı Kadıhan (fi'l-fikhi'l-Hanefî)" adıyla da mukayyeddir. ${ }^{23}$

\footnotetext{
19 “Vaka'a’l-ferâğu min te'liffihâ ve tesvîdihâ fî evâsıti zi'l-hicce sene ihdâ ve tis‘a-mi’e (vr. 230/12-13).

${ }^{20}$ Staatsbibliothek, Berlin, Ms. or. quart. 1480 (Götz II (VOHD XIII, 4), 269, Nr. 284); Staatsbibliothek, Berlin, Ms. or. oct. 2349/1 (Götz II (VOHD XIII, 4), 270, Nr. 285); Staatsbibliothek, Berlin, Ms. or. oct. 2349/2 (Götz II (VOHD XIII, 4), 271, Nr. 286); Österreichische Nationalbibliothek H.O. 162 (Flügel I, 242-243, Nr. 248); Bibliothèque Nationale de France, supp. Turc 107 (Blochet I, 213, Nr. 107); Dârü’l-Kütübi’l-Kavmiyye, el-Edebü’t-Tîmûriyye, Nr. 238 (Fihrüsü Mahtûtâti’t-Türkiyyeti'l-Osmâniyye, III, 320, Nr. 4106); Kütübhâne-i Büzürg-i Hazret-i Ayetu’llâhi’lUzmâ Mar'aşî Necefî 9981 (Muttakî I, 224, Nr. 164); İzmir Millî Ktp. 1901 (Yardım III, 325, Nr. 3703); Bursa, Yazma ve Eski Basma Eserler Ktp., Haraççıŏlu 996 (Ergin TDED IV, 118); Manisa İl Halk Ktp. 2781, 2782, 6450 (Gönültaş Nr. 160); Süleymaniye Ktp. Muğla Hoca Mustafa Efendi 800 (Şeşen 387, Nr. 64); Süleymaniye Ktp. Yazma Bağışlar 5502/1; Hacı Selim Ağa, Kemankeş 525/1; Beyazıt Devlet Ktp. Veliyyüddin Efendi 2697/7 ("Hülâsa-i Gülşen-i İnşâ”); Millet Ktp., Ali Emirî, Edebiyat 368; İstanbul Üniversitesi Edebiyat Fakültesi Genel Ktp., Türk Dili ve Edebiyatı Bölümü Seminer kitaplığı 3780; Türk Tarih Kurumu Ktp., Y/504; Millî Ktp. 06 Mil Yz A 2276; Millî Ktp. 60 Zile 117 (krş. Şeşen 387, Nr. 64); Millî Ktp. 26 Hk 334/3 (TÜYATOK 26, 344, Nr. 816).

${ }^{21}$ Karatay III, 25, Nr. 4754. Ayrıca bk. Karabulut-Karabulut V, 3576, Nr. 9698/1 ("Hâşiyetü 'alâ Şerhi'l-'Akâ’idi’nNesefiyye" adiyla).

${ }^{22}$ Ahmet Özel, "Kâdîhân”, DİA XXIV, 122.

23 Karabulut III, 1500, Nr. 5024/2; Karabulut-Karabulut V, 3576, Nr. 9698/3. Biz, müellif nüshasının

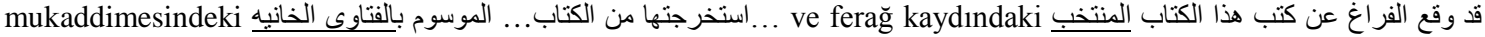
ibarelerine dayanarak eserin adını Şehit Ali Paşa nüshasındaki gibi “Müntehabü'l-Fetâva'l-Hâniyye” olarak aldık.
} 


\section{Tuhfetü'l-Edeb}

Şeyh Mahmud bin Edhem'in Arapçanın sarfıyla ilgili Türkçe eseridir. Müellif nüshası Beyazıt Devlet Kütüphanesinde, müellifin diğer eseri Minhâcü’l-Edeb ile aynı cilttedir.

Beyazit Devlet Ktp., Beyazit 6700/2.

Müellifin talik hattıyla, Türkçe, 180x130, 125x75 mm ölçülerinde, 15 satırlı, vr. 52b79a arasında. 72b-73a arasından bir veya iki varak kopmuştur. Başlıklar kırmızı mürekkeple yazılmıştır. Kahverengi meşin ciltlidir. Telif tarihi: 900/1494-1495.

\section{Başı (52b):}

Bismi’llâhi’r-rahmâni’r-rahîm ve'l-i‘tisâmu bi-meyâmini ismihi’l-‘azîm

El-hamdulillâhi rabbi'l-‘âlemîn ve’s-salâtu 'alâ seyyidi’l-mürselîn ve 'alâ âlihi ve sahbihi ecmâ‘în. Eyâ kurrete'l-‘ayn, es'adeke’llâhu fi'd-dâreyn. Bil kim 'ilm-i sarf kelimât-1 müştakanuñ vezn ü sîgasın ve iştikâk u i‘lâlin beyân ider.

\section{Sonu (79a):}

Temme tesvîdü’r-risâleti’l-müsemmâti bi-Tuhfeti’l-Edeb bi-‘avni’llâhi te‘âlâ ve hüsni tevfîkihi. Ve kad feraga min tedvînihâ ahkaru'l-‘ibâd Şeyh Mahmûd bin Edhem el-mürtecî ‘avârife rabbihi’l-ekrem. Ve vaka'a'l-ferâgu fî evâsiti ramazâni’lmübâreki min şühûri sene tis‘a-mi’e [= Ramazan ayının ortaları 900/Haziran 1495]. Ve'l-hamdulillâhi 'ale’l-itmâm ve 'alâ resûlihi efdalu's-selâm ve âlihi ve sahbihi’lkirâm. Temm.

Şeyh Mahmud bin Edhem, Arapçanın sarfı (=morfoloji) ile ilgili bu Türkçe eserini oğlunun eğitimi için yazmıştır. Konu itibariyle Minhâcü'l-Edeb gibi Arapçanın sarfından aksam-ı seb ‘ayı ele alan bu eser, dili yönüyle ondan ayrılır. Minhâcü’l-Edeb Arapça, Tuhfetü’lEdeb ise Türkçedir. Aynı konuda yazılmış bu iki muhtasar eserden biri diğerinin birebir tercümesi değildir.

Tuhfetü'l-Edeb'in mukaddimesinde türemiş kelimeler (“kelime-i müştaka”) hakkında bilgi verilmiştir. Müellif, türemiş kelimeleri isim ve fiil olarak iki gruba; ismi yedi, fiili ise altı alt gruba ayırmıştır:

Kelime-i müştaka "Kelime-i müştaka iki kısımdur ki ism ü fiildür”

I. İsim "İsm-i müştak yidi kısımdur" 
1. İsm-i fâil

2. İsm-i mefûl

3. Sifat-1 müşebbehe

4. İsm-i tafdîl

5. İsm-i zaman

6. İsm-i mekân

7. İsm-i alet

II. Fiil "Fiil altı kısımdur"

1. Fi'l-i mazi

2. Fi'l-i muzari

3. Emir

4. Nehy

5. Cahd

6. Nefy

“Cümle kelimât-1 müştaka on üç kısm oldı” (vr. 52b/7-8)

Müellif daha sonra "masdardan türeyen fiiller"i ele alır ki bunlar da toplam otuz beş babdır: "Ammâ ef'âl ki masdardan müştak olur, otuz biş bâbdur" (vr. 52b/11-12). Müellif bu otuz babı şu şekilde tasnif etmiştir:

1. Mücerred

1. Sülâsî-i mücerred: Altı bab

2. Rübâî-i mücerred: Bir bab

\section{Mezîd}

1. Mezîd-i sülâsî: Üç alt gruba ayrılmış toplam on iki bab.

2. Mezîd-i rübâî: İki alt gruba ayrılmış toplam üç bab. 
3. Mülhak

1. Rübâî-i mücerrede mülhak: Altı bâb.

2. Mezîd-i rübâîye mülhak: İki alt gruba ayrılmış toplam yedi bab.

Müellif mukaddimede bu bilgileri k1saca verdikten sonra eserini yedi bab ("ebvâb-1 tasrîf” vr. 56b/5) üzerine tasnif eder.

"Ebvâb-1 tasrîf” (=aksâm-1 seb'a):

1. el-bâbü’l-evvel fi’s-sahîh (57a/1-68b/3)

2. el-bâbü’s-sânî fi’l-muzâaf (68b/4-70a/12)

3. el-bâbü’s-sâlis fi’l-mehmûz (70a/12-72b/15 sondan eksik)

4. [el-bâbü’r-râbi ‘ fi’l-misâl (?-?) eksik]

5. [el-bâbü’l-hâmis fi’l-ecvef] (73a/1-74b/13 baştan eksik)

6. el-bâbü’s-sâdis fi’n-nâkıs (74b/13-77a/14)

7. el-bâbü’s-sâbi‘ fi’l-lefîf (77a/15-79a/1)

Müellif "tasrîfün ebvâb-1 seb'ası" olarak nitelediği bu yedi babdan her birine giren türemiş kelimelerin (kelimât-ı müştaka") türetme (iştikâk) kurallarını ve kiplerini (sîga) verir, tasrifini (çekimini) yapar (vr. 68b/1-2).

Arapçanın morfolojisi (=sarf) ile ilgili bu Türkçe eserde kullanılan dilbilgisi terimleri Arapçadır.

\section{Sonuç}

Şeyh Mahmud bin Edhem, II. Bayezit devri (saltanatı: 1481-1512) âlimlerindendir. Dil bilgisi, sözlük, inşa, akaid ve fikıh dallarında toplam sekiz eseri bulunmaktadır.

Tuhfetü'l-Edeb, Şeyh Mahmud bin Edhem'in Arapçanın sarfını (şekil bilgisi/morfoloji) konu alan Türkçe eseridir. Müellifin sarf ilmini tahsile başlayan oğlu için hazırladığ 1 bu eserin tertibi farklı olsa da muhtevası, Osmanlı medreselerinde başlagıç seviyesinde ders kitabı olarak okutulan müellif ve telif tarihleri bilinmeyen Emsile ve Binâ kitaplarıyla aynıdır. Emsile’de fiil çekimi, Binâ' da vezinler/iştikak (kelime türetme) ele alınmıştır. Tuhfetü'l-Edeb'de ise vezinler ve fiil çekimi iç içe işlenmiştir. 
Tuhfetü'l-Edeb'de kullanılan dilbilgisi terimleri Osmanlı Türkçesi gramerlerinde de kullanılan Arapça terimlerdir. Eser, Osmanlı Türkçesindeki Arapça unsurların kavranması açısından önemlidir.

\section{Kaynaklar}

Bayoğlu, S. (Proje Yürütücüsü) (2002). Türkiye yazmaları toplu kataloğu [=TÜYATOK] 26. Eskişehir İl Halk Kütüphanesi Yazmaları Kataloğu. Ankara: T. C. Kültür Bakanlığ1 Yayınlar1.

Blochet, E. (1932-1933). Catalogue des manuscrits Turcs. 2 C. Paris.

Bursalı Mehmed Tahir (1333-1342). Osmanlı müellifleri. 3 C. İstanbul: Matbaa-i Âmire [=Devlet Matbaası]. (Tıpkıbasım: Ahmed Remzi Akyürek (2000). Miftâhu’l-Kütüb ve Esâmî-i Müellifîn Fihristi ile birlikte. Ankara: Bizim Büro Basımevi).

Cunbur, M. (2006). Mahmûd b. Edhem. Türk dünyası edebiyatçıları ansiklopedisi [=TDüEA] VI. 190. Ankara: Atatürk Kültür Merkezi Yayınları.

Çetin, A. (2014). Şeyh Mahmûd bin Edhem: miftâhu’l-luga. Ankara: Sonçă̆g.

Devellioğlu, F. (2005). Osmanlıca-Türkçe ansiklopedik lûgat. Ankara: Aydın Kitabevi.

Eminoğlu, M. (1997). Koyunoğlu müze ve kütüphanesi yazma eserler kataloğu I. Konya: Konya Büyükşehir Belediyesi Kültür Yayınları.

Ergin, M. (1950). Bursa kitaplıklarındaki Türkçe yazmalar arasında. İstanbul Üniversitesi Edebiyat Fakültesi Türk Dili ve Edebiyatı Dergisi [=TDED], IV, 1-2, 103-132.

Fihrüsü Mahtûtâti’t-Türkiyyeti’l-Osmâniyye, Kahire 1990, 4 C.

Flügel, G. (1977). Die Arabischen, Persischen und Türkischen handschriften der kaiserlichköniglichen hofbibliothek zu wien. 3 C. Wien 1865. (Tıpkıbasım: Hildesheim: Georg Olms).

Gönültaş, G. (1986). Manisa il halk kütüphanesi Türkçe el yazmaları kataloğu. Manisa: Türkiye Kütüphaneciler Derneği Manisa Şubesi Yayınları.

Götz, M. (1979). Türkische handschriften, (VOHD (=Verzeichnis der Orientalischen Handschriften in Deutschland) XIII, 4). Wiesbaden. 
Gültekin, H. (2014). Şeyh Mahmûd bin İbrâhîm Edhem, Şeyh Mahmûd bin Edhem (d.?/?ö.897/1491-92). Türk Edebiyatı Ísimler Sözlüğü, http://www.turkedebiyatiisimlersozlugu.com/index.php?sayfa=detay\&detay=2680 (Madde yazım tarih: 15.05.2014; Erişim tarihi 20.07.2014).

Karabulut, A. R. (tarihsiz). İstanbul ve Anadolu kütüphanelerinde mevcut el yazması eserler ansiklopedisi. 3 C. Kayseri.

Karabulut, A. R.-A. T. Karabulut. (tarihsiz). Dünya kütüphanelerinde mevcut İslâm kültür tarihi ile ilgili eserler ansiklopedisi. 5 C. Kayseri: Mektebe Yayınları.

Karatay, F. E. (1962-1969). Topkapı sarayı müzesi kütüphanesi arapça yazmalar kataloğu. 4 C. İstanbul.

Kâtip Çelebi (1941-1943). Keşf el-zunun. (haz. Şerefettin Yaltkaya-Kilisli Rifat Bilge). 2 C. İstanbul: Millî Eğitim Bakanlığı Yayınları.

Kaya, H. (1996). Şeyh Mahmud Bin İbrahim Edhem: miftahu'l-luga (Inceleme-Metin-Dizin). Yayımlanmamış yüksek lisans tezi, Ankara: Ankara Üniversitesi Sosyal Bilimler Enstitüsü.

Mehmed Süreyya (1996). Sicill-i Osmanî. (Eski Yazıdan Aktaran: Seyit Ali Kahraman). 6 C. İstanbul: Kültür Bakanlı̆̆ı-Tarih Vakfi.

Muttakî, H. (1381/1423). Fihrist-i nüshâhâ-yi hattî-i Türkî, kütübhâne-i büzürg-i hazret-i ayetu'llâhi'l-uzmâ mar 'aşî Necefî. Kum.

Özel, A. (2001). Kâdîhân. DİA XXIV, 121-123. Ankara: Türkiye Diyanet Vakfı Yayınları.

Sübhânî, H. T. (1368). Fihrist-i nüshâhâ-yi hattî-i Fârsî-i, kütübhâne-i Burûsa. Neşr-i Dânişkede-i Gîlân.

Şeşen, R. (1978). Türkiye kütüphanelerinde bulunan bazı nâdir Türkçe yazmalar. İstanbul Üniversitesi Edebiyat Fakültesi Tarih Enstitüsü Dergisi, 9, 373-404.

Şeyh Mahmûd b. Edhem. Gülş̧en-i inşâ. Süleymaniye Ktp., Kadızade Mehmed 421.

Şeyh Mahmûd b. Edhem. Miftâhu’l-luga. Millî Ktp. 06 Hk 141/1.

Şeyh Mahmûd b. Edhem. Miftâhu’l-luga. Österreichische Nationalbibliothek A. F. 448/1.

Şeyh Mahmûd b. Edhem. Miftâhu’l-luga. Süleymaniye Ktp, Kara Çelebizade 341. 
Şeyh Mahmûd b. Edhem. Minhâcü'l-edeb. Beyazıt Devlet Ktp., Beyazıt 6700/1.

Şeyh Mahmûd b. Edhem. Muhtasaru'l-îzâh. Koyunoğlu Müze ve Ktp. 842.

Şeyh Mahmûd b. Edhem. Tuhfetü’l-edeb. Beyazıt Devlet Ktp., Beyazıt 6700/2.

Tar, S.(1968). XIII. yüzylldan beri türkiye türkçesiyle yazılmış kitaplardan toplanan tanıklarıyla tarama sözlüğ̈̈. 8 C. Ankara: TDK Yayınları.

TDEA (1977-1998). Türk dili ve edebiyatı ansiklopedisi: devirler, isimler, eserler, terimler. 8 C. İstanbul: Dergâh Yayınları.

TDÜEA: Türk dünyası edebiyatçıları ansiklopedisi bk. Cunbur, M.

Tekin, Ş. (1971). Menâhicü'l-inşâ, the earliest Ottoman chancery manuel by Yahya bin Mehmed el-Katib from the 15. century. Roxbury: Community Art Workshop.

TÜYATOK bk. Bayoğlu, S.

Uzunçarşıll, İ. H. (2011). Osmanlı tarihi. 4 C. Ankara: TTK Yayınları.

Yardım, A. (1992-1997). İzmir millî kütüphanesi yazma eserler kataloğu. 4 C. İzmir: İzmir Millî Kütüphane Vakfi.

Yavuz, M. (1991). Kuruluştan fatih devri sonuna kadar Arapça gramer (sarf-nahiv)'e dâir eser yazan Osmanll-Türk âlimleri. Yayımlanmamış Yüksek Lisans Tezi. İstanbul: İstanbul Üniversitesi Sosyal Bilimler Enstitüsü.

Yavuz, S. S. (2002). Kestelî. DİA XXV, 314. Ankara: Türkiye Diyanet Vakfı Yayınları. 


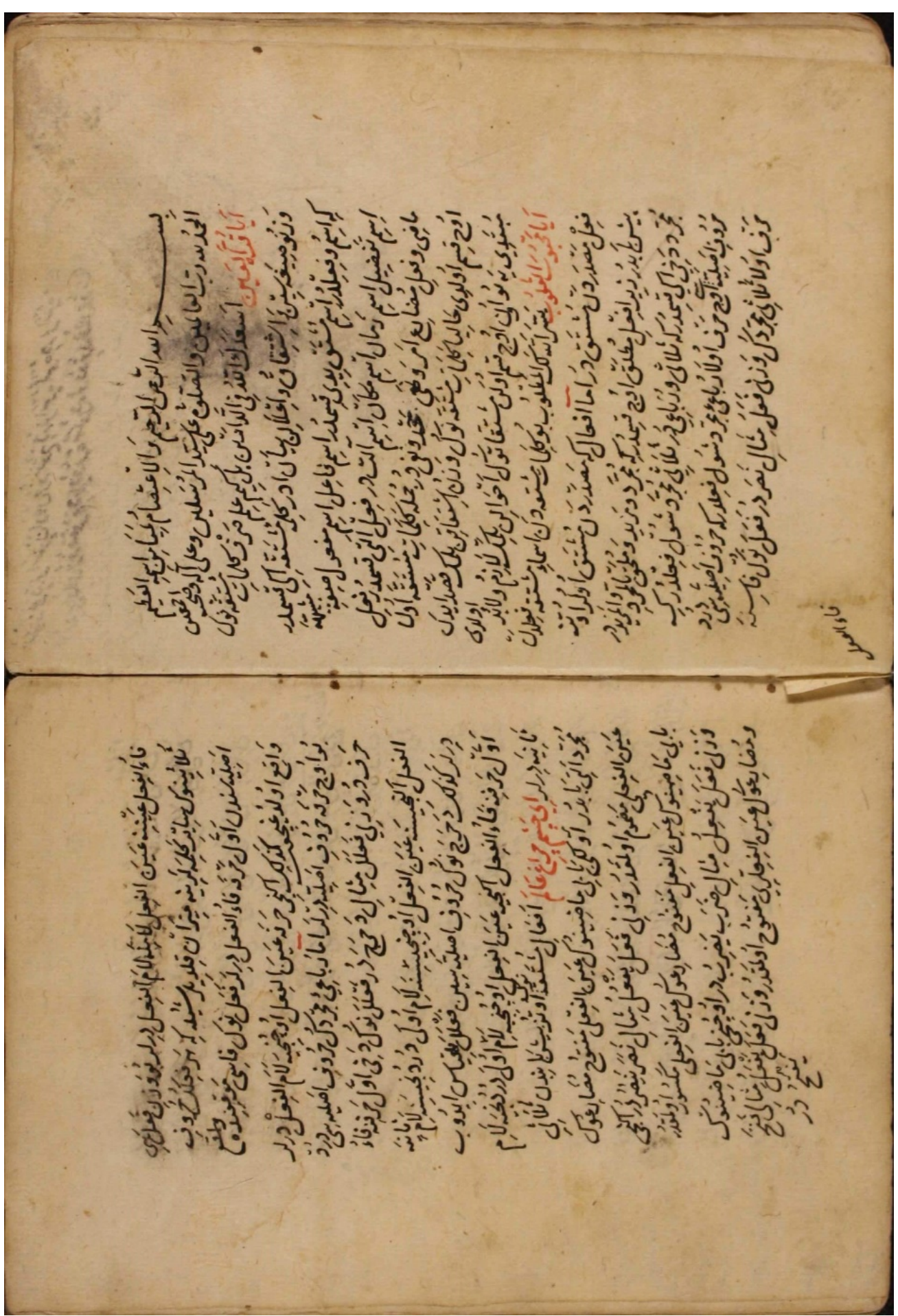

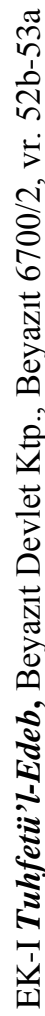




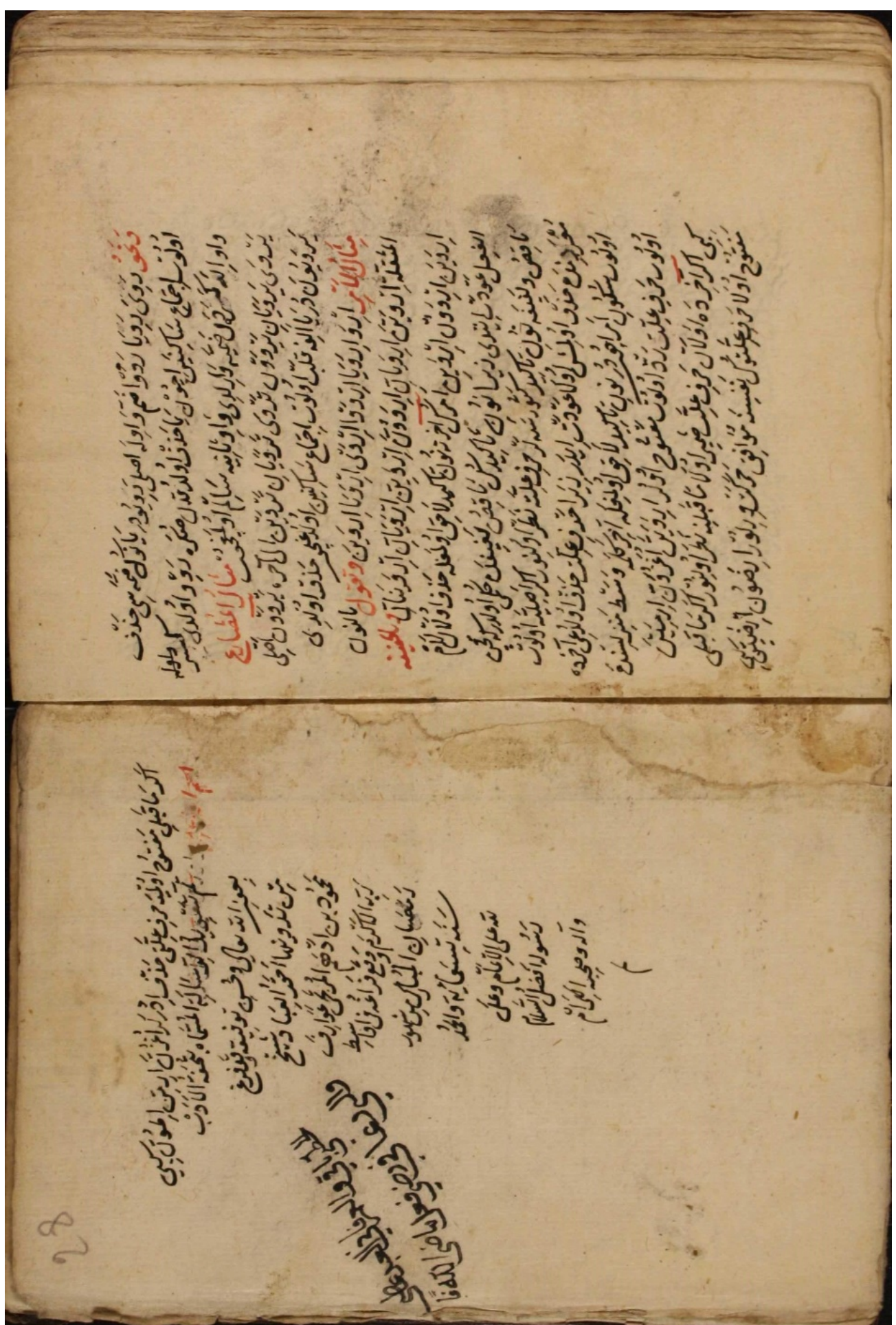

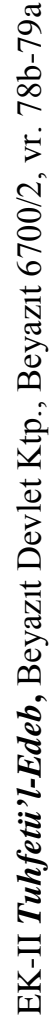

